\title{
Die belangrikheid van besoeke aan nuwe intrekkers as deel van die werkprogram van die gemeente- predikant
}

\section{P J van Zyl \& T F J Dreyer \\ Universiteit van Pretoria}

\begin{abstract}
The importance of visits to newcomers as part of the workprogramme of the parish minister

In the current theological literature about parish-visiting, a gap is identified with regard to the importance of visiting newcomers in a congregation. With this in mind an empirical study was undertaken to evaluate the matter in actual practice. The starting point (hypothesis) of this study is: Visits to newcomers is a very important facet of any parish minister's work. Such visits can help to establish a pastoral relationship between minister and member which is essential for the minister's pastoral and other work in the congregation. By means of an empirical study the above-mentioned hypothesis was tested and a preliminary theory with regard to the importance of visitation to newcomers was formulated. After this theory has been tested against the directives of Scripture, a proposal is made for a new theory to underpin the practice within the Nederduitsch Hervormde Kerk van Afrika.
\end{abstract}

\section{INLEIDING}

Daar is geen plaasvervanger vir huisbesoek nie. Huisbesoek, gereelde huisbesoek is ' $n$ moet.

(Booysen 1990:567).

Indeed, in our day of sprawled-out cities, modern communication, rapid transportation et cetera, making house calls is probably one of the most ineffective and inefficient methods of visitation available.

(Adams 1981:77).

* Hierdie artikel is gebaseer op navorsingsresultate verkry in die doktorale proefskrif van P J van Zyl, ingedien en aanvaar as deel van die vereistes vir die DD-graad (1995), Departement Praktiese Teologie, Fakulteit Teologie (Afd A), Universiteit van Pretoria, onder leiding van prof dr T F J Dreyer. 
Niet voor niets heeft het huisbezoek bij veel gemeenteleden en pastores nog altijd een nare bijklank.

(Heitink 1982:303).

Der traditionele Hausbesuch is unnersetzbar und gerade heute, inmitten starker tendenzen zur anonytät, vom großer Bedeutung als Echo und Hinweis auf die fröhe Botshaft, daß Gott uns beim Namen gerufen hat (Jes 43:1).

(Van der Geest 1981:191).

Bogenoemde en ander teenstrydige uitsprake wat in die literatuur aangetref word (vgl Die Hervormer 1990:11, 18; 1991:20, 21; Wagenaar [1984]:89; Horton 1981:100; Müller 1985:311; Die Kerkbode 1991:3, 12, 14; Bouwman 1928:555; Deddens 1988: 161; Piper 1985:5), werp 'n ernstige refleksie op die geldigheid van bestaande praktiesteologiese teorieë oor huisbesoek. Verder word daar in die literatuur oor huisbesoek telkens melding gemaak van 'n positiewe verband tussen huisbesoek en erediensbywoning sonder dat dit empiries geverifieer word (vgl Horton 1981:100; Hocking 1985:49; Kuyper 1980:38; Dixon 1976:264; Dixon 1987:18).

Met dit in gedagte, het die ondersoeker 'n empiriese studie onderneem om te bepaal of daar statisties enige korrelasie tussen huisbesoek en erediensbywoning bestaan (vgl Van Zyl 1995). Om so 'n korrelasie te kon bepaal, was dit nodig om die bestaande teologiese teorieë oor huisbesoek en erediens/erediensbywoning deur middel van deduksie bloot te lê. Daarna is die teologiese teorieë empiries getoets en die korrelasie bepaal.

In die proses is daar ' $n$ leemte geïdentifiseer wat nie in die bestaande teologiese literatuur oor huisbesoek na vore kom nie (in 'n mindere mate by Berkelbach van der Sprenkel 1946:32), naamlik die belangrikheid van besoeke aan nuwe intrekkers. Aangesien die vermoede by die ondersoeker bestaan het dat dit wel 'n belangrike faset van 'n gemeentepredikant se werk behoort te wees, is dit empiries getoets en die resultate word hier weergegee.

Die volgende hipotese is as vertrekpunt gestel: Besoeke aan nuwe intrekkers is 'n belangrike faset van enige gemeentepredikant se werksaamhede. Sodanige besoeke kan meehelp in die vestiging van 'n pastorale relasie tussen predikant en lidmaat wat 'n belangrike funksie vervul in die predikant se pastorale en ander werksaamhede in 'n gemeente.

\section{Metodologiese verantwoording}

Die doel van die Praktiese Teologie kan omskryf word as die ontwikkeling (op 'n wetenskaplike wyse) van nuwe teorieë vir die praktyk deur bestaande teorieë te toets, te 
herstel en/of, indien nodig, te verander (vgl Vos \& Muller 1991:86; Lemmer 1991:12; Pieterse 1986:64-66). In die proses waar teorieë getoets, herstel en/of yerander word, kom 'n mens onmiddellik voor die teorie/praxis-probleem te staan. Daarom sal daar van 'n metode gebruik gemaak moet word om hierdie probleem voortdurend te balanseer. Die gevaar bestaan altyd dat die een bo die ander gestel kan word (vgl Heyns \& Pieterse 1990:29-35; Nel 1991:22-23). In hierdie verband bied die model van Zerfass (1974:164-169) 'n nuttige vertrekpunt. Tog het die model een groot leemte, naamlik dat daar nie 'n normatiewe posisie aan die Bybel toegeken word nie (vgl Heyns \& Pieterse 1990:39). Vir Zerfass vorm die Bybel deel van die teologiese tradisie wat beteken dat dit op gelyke vlak met al die ander kerklike oorleweringe te staan kom.

Deur middel van ' $n$ paar verskuiwings aan sy model word 'n normatiewe posisie (vgl Dreyer 1991:607) aan die Bybel toegeken, terwyl dit nog steeds moontlik is om 'n sinvolle teorie/praxis-verhouding daar te stel.

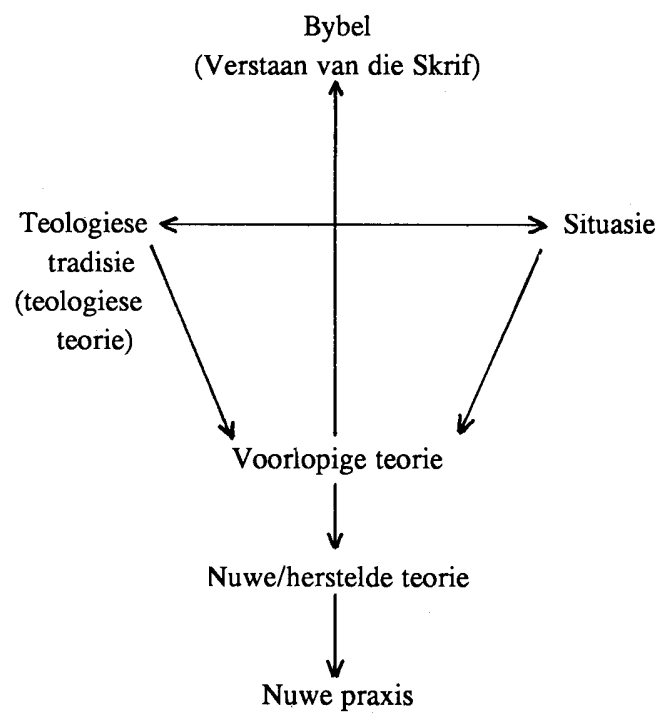

Gewysigde model 
In hierdie artikel word 'n normatiewe posisie aan die Skrif toegeken. In aansluiting by Louw (1993:379) word die stelling gemaak dat die Skrifwaarheid nie verifieerbaar in terme van wetenskaplike bewyse is nie, maar dat dit betroubaar is omdat die betroubaarheid van die Skrifwaarheid gewaarborg word deur die trou van God. Dit is 'n geloofspremisse wat die ondersoeker as vertrekpunt neem.

In 'n prakties-teologiese ondersoek word, volgens bogemelde model, die resultate van die deduktiewe literatuurstudie na die bestaande teologiese teorieë, en die praxis (empiries vasgestel) in interaksie met mekaar gestel. So kan 'n voorlopige teorie oor 'n bepaalde saak gestel word. Deur hierdie voorlopige teorie hermeneuties aan die riglyne van die Skrif te toets, kan 'n nuwe of verstelde praktykteorie volg wat tot 'n nuwe (moontlik verbeterde) praxis kan lei.

Aangesien daar in die inleiding reeds gestel is dat daar geen teorie met betrekking tot besoeke aan nuwe intrekkers in die literatuur gevind kon word nie, word daar onmiddellik oorgegaan na die tweede stap van die ondersoek, naamlik om die hipotese in die praktyk te toets.

\section{Empiriese ondersoek}

\subsection{Biografiese inligting}

Alvorens die inligting ten opsigte van die besoeke aan nuwe intrekkers weergegee word, is dit nodig om ter wille van oriëntasie, inligting te verskaf oor die metode van ondersoek en bekend te maak wie aan die ondersoek deelgeneem het.

Die gemeentes van die Nederduitsch Hervormde Kerk van Afrika (Nederduitsch Hervormde Kerk van Afrika $=$ NHKA) is in drie kategorieë ingedeel, te wete stedelik /groot dorp, platteland en 'n derde kategorie wat vir dié doel kategoriaal genoem word en uit studente-, weermag-, polisie- en middestadgemeentes bestaan. 'n Ewekansige steekproef is uit die drie kategorieë op 'n wetenskaplike manier (rekenaarmatig) uit gemeentes wat aan die ondersoek deelgeneem het, geneem. (vgl Van Zyl 1995:195202). Die getal van 1634 wat noodsaaklik vir dié steekproef is (vgl Stoker 1981:12, 13 ), is deur middel van ' $\mathrm{n}$ formule, steekproefgrootte $=$ die vierkantswortel van $20 \mathrm{xN}$ ( $\mathrm{N}=$ populasie-grootte), bepaal. Uiteindelik is 1620 vraelyste aan 20 gemeentes (stad/groot dorp 12, platteland 5, kategoriaal 3) van die NHKA gestuur met spesifieke opdragte oor die wyse waarop dit versprei moes word. Van die 1620 vraelyste wat uitgestuur is, is $668(41 \%)$ terugontvang.

Van die 668 vraelyste wat terugontvang is, is $334(50,5 \%)$ deur manlike en 327 $(49,5 \%)$ deur vroulike respondente (7 het nie hulle geslag aangedui nie) voltooi. Wat die huwelikstaat van die respondente betref, kon die respondente hulleself in een van vyf kategorieë plaas, te wete getroud, ongetroud, geskei, wewenaar en weduwee. Die volgende grafiese voorstelling bied 'n duidelike beeld van die respondente se huwelikstaat tydens die ondersoek: 
Figuur 1

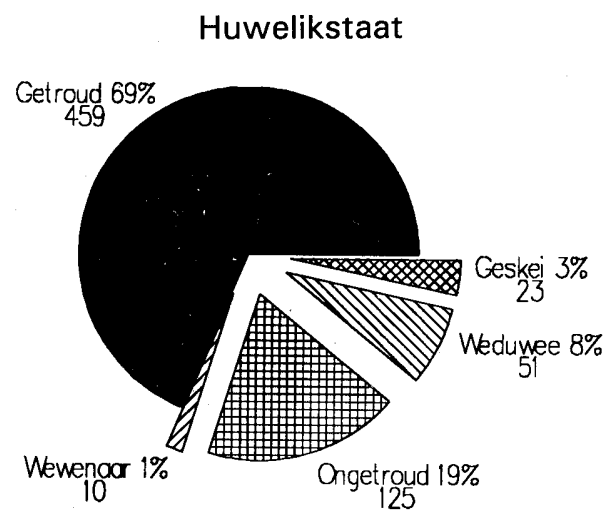

Huwelikstaat van al die respondente

Uit die voorstelling is dit duidelik dat die meerderheid respondente wat aan die ondersoek deelgeneem het, ten tyde van die ondersoek getroud was.

Met betrekking tot die ouderdom van die respondente, toon die volgende grafiese voorstelling ' $n$ redelike verspreiding tussen al die ouderdomsintervalle in al drie kategorieë.

Figuur 2
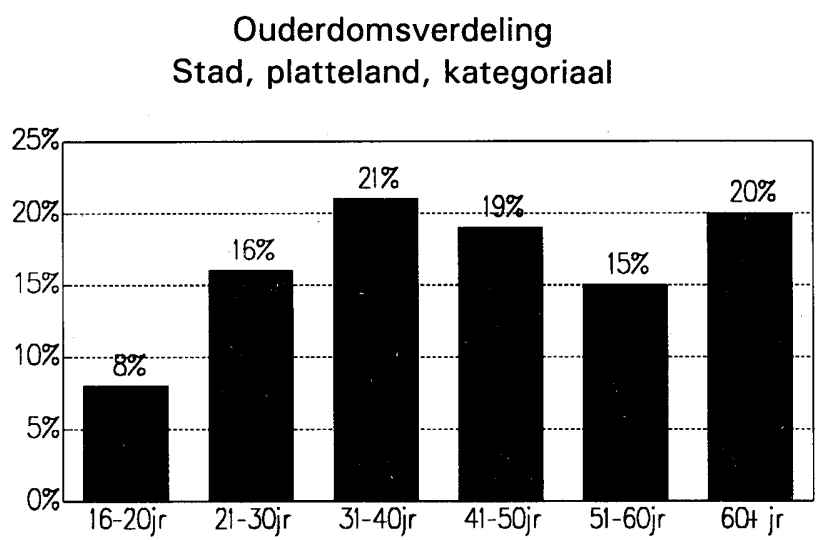

Series 1

Ouderdomsverdeling van al die respondente 


\subsection{Besoeke aan nuwe intrekkers}

Die argument wat hier aangevoer word, spruit voort uit een van die doelwitte wat in die genoemde literatuurondersoek oor huisbesoek uitgewys en deur die empiriese ondersoek onderstreep is ( $\mathrm{vgl}$ Van Zyl 1995:237-241), naamlik dat die vestiging van 'n pastorale relasie tussen die predikant en lidmaat 'n baie belangrike doelwit van huisbesoek behoort te wees. Lidmate het in genoemde ondersoek aangetoon dat hulle die vestiging van so 'n pastorale relasie as baie belangrik ag. Hulle moes 6 moontlike doelwitte van huisbesoek in volgorde van belangrikheid rangskik. In die onderstaande tabel (Tabel 1) word die volgorde waarin die meeste lidmate (gemiddeld) in die drie kategorieë dit gerangskik het, aangedui.

Die volgende moontlikhede moes gerangskik word:

* Huisbesoek moet help om my geloof sterk te maak (geloof versterk).

* Huisbesoek moet die gemeente nader aan mekaar bring (gemeente nader bring).

* Huisbesoek moet my aanspoor om meer betrokke te wees in die gemeente (my aanspoor).

* Huisbesoek moet my help in die lewe van elke dag (lewe help).

* Huisbesoek moet so 'n verhouding met die predikant skep dat ek die vrymoedigheid het om my probleme met hom te bespreek (verhouding skep).

* Huisbesoek is 'n geleentheid waar die lidmaat se lewe aan die eise van die Bybel getoets kan word (my lewe toets).

Ter wille van ' $n$ beter vergelyking word dit reeds in Tabel 1 in die volgorde (van 1 tot 6) waarin die lidmate dit gerangskik het, geplaas. Dit beteken dat die nommer wat langs die afkorting staan, nie noodwendig ooreenstem met die nommers wat hierbo gegee is nie. Die respondente het die ses moontlikhede as volg in prioriteitsorde van 16 gerangskik: 
Tabel 1 - Die doel van huisbesoek - lidmate se indeling

\begin{tabular}{|l|l|l|}
\hline & & \\
Stad/groot dorp & Platteland & Kategoriaal \\
$*$ Verhouding skep & $*$ Verhouding skep & $*$ Geloof versterk \\
$*$ Geloof versterk & $*$ Geloof versterk & $*$ My aanspoor \\
$*$ My aanspoor & $*$ My aanspoor & $*$ Lewe help \\
$*$ Lewe help & $*$ Gem nader bring & $*$ Gem nader bring \\
$*$ Gem nader bring & $*$ Lewe help & $*$ My lewe toets \\
\hline My lewe toets & $*$ My lewe toets & \\
\hline
\end{tabular}

Hieruit is dit baie duidelik dat lidmate die teologiese teorie, naamlik dat die vestiging van 'n pastorale relasie (verhouding skep) tussen pastor en lidmaat baie belangrik is, beaam. In die kategorie Stad/groot dorp en Platteland beskou die respondente dit as die belangrikste doel van huisbesoek terwyl die lidmate van die kategoriale gemeentes dit tweede geplaas het. As die afleiding hieruit gemaak kan word dat die vestiging van 'n persoonlike/pastorale relasie tussen die predikant en die lidmaat 'n belangrike doel van huisbesoek kan en moet wees, sal dit die beplanning van die huisbesoek in 'n gemeente beslis raak. In die eerste plek sal dit belangrik wees dat 'n predikant wat in 'n nuwe gemeente begin werk, tyd sal inruim om elke lidmaat in die gemeente so spoedig as moontlik te ontmoet. Dit kan deur middel van 'n kort kennismakingsbesoek aan elke gesin, of deur groepsbyeenkomste plaasvind waar gepoog word om soveel as moontlik van die lidmate te ontmoet.

In die tweede plek sal die besoeke aan nuwe intrekkers in die gemeente deur die predikant voortdurende prioriteit moet geniet. Dit geld veral daar waar die vestiging van 'n pastorale relasie wel vir die predikant en kerkraad 'n belangrike doel van huisbesoek vorm en die predikant reeds 'n geruime tyd in die gemeente werk en dus die grootste persentasie lidmate ken. Dit kan daartoe lei dat 'n lidmaat/gesin so gou moontlik nadat hulle in 'n nuwe gemeente ingetrek het, ingeskakel word. Indien dit nie gedoen word nie, kan die predikant se pastoraat en die lidmaat se betrokkenheid direk daardeur beïnvloed word.

Lidmate het met ' $\mathrm{n}$ beduidende persentasie $(76 \%)$ aangedui dat dit vir hulle belangrik is om die predikant tydens die huisbesoek persoonlik te leer ken. Dit is verder vir hulle (86\%) makliker is om met 'n persoonlike probleem na die predikante te gaan as hulle hom reeds tydens huisbesoek persoonlik leer ken het (vgl Van Zyl 1995:235, 236). Die besoeke aan nuwe intrekkers kan dus van groot waarde wees vir die vestiging van 'n pastorale relasie (persoonlik leer ken) sowel as vir die predikant se pastorale werk in die algemeen. 
Dit kan, soos deur Berkelbach van der Sprenkel (1946:32) voorgestel word, 'n geleentheid wees waar inligting uitgeruil word. Sekere belangrike gegewens oor die gemeente kan byvoorbeeld aan die lidmaat meegedeel word terwyl 'n uitnodiging tot deelname en inskakeling direk en persoonlik aan hom of haar gerig kan word. Belangrike informasie aangaande die.gesin kan ook tydens die besoek ingewin word. Dit sal goed wees as die predikant self hierdie besoek bring, al is dit net 'n vinnige inloer wat tien/vyftien minute duur.

Indien nuwe intrekkers nie kort na hulle aankoms deur die predikant besoek word nie, kan dit soms in die praktyk so lank as twee jaar en selfs langer duur voordat die predikant die geleentheid kry om die bepaalde gesin te ontmoet. Gestel dit neem twee jaar of langer vir 'n predikant om elke huisgesin in ' $n$ bepaalde gemeente te besoek en 'n nuwe gesin sou intrek in 'n wyk waar die predikant kort tevore huisbesoek gedoen het, beteken dit dat die predikant eers oor twee jaar weer in daardie wyk huisbesoek doen en moontlik dan eers die geleentheid sal kry om dié gesin te ontmoet. Die probleem wat só 'n situasie skep, is voor die handliggend (vgl ook Piper 1985:19; Kaptein 1975:31, 52).

As die probleme wat deur verstedeliking meegebring word, soos onder andere anonimiteit, mobiliteit, vereensaming, die verdwyning van die indiwidu tussen die massa, gejaagdheid, en 'n gebrek aan kommunikasie (vgl Louw 1980a:41-46), hiermee saamgeneem word, word die belangrikheid van besoeke aan nuwe intrekkers nog duideliker. Lidmaatrespondente het met $98 \%$ aangedui dat hulle dit verkies dat die predikant hulle binne drie maande nadat hulle in 'n nuwe gemeente ingetrek het, besoek om kennis te maak. Die volgende grafiese voorstelling spreek vanself. Die ooreenkomste tussen die drie kategorieë is so groot dat hulle saam aangedui word:

Figuur 3

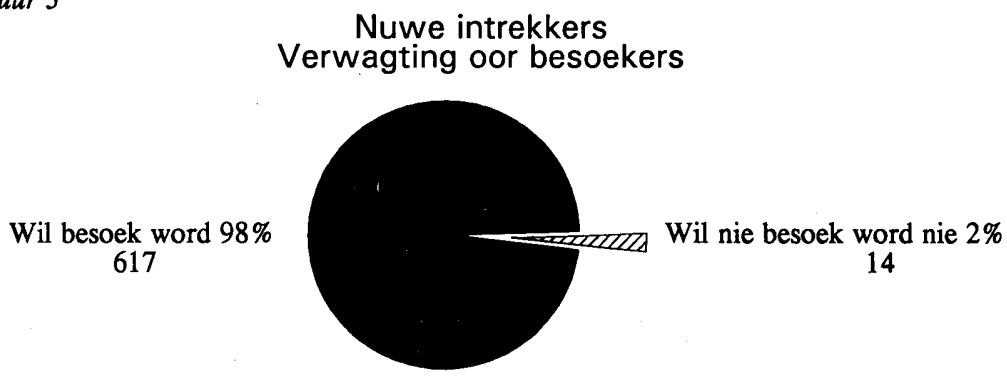

Nuwe intrekkers se verwagting ten opsigte van besoeke aan hulle

Dit is interessant om te let op die geslagte se beoordeling van die saak. Van die $98 \%$ respondente in die stad/groot dorp wat positief op die vraag gereageer het, is $47 \%$ manlik en $51 \%$ vroulik. In die platteland het $56 \%$ mans gevoel dat hulle graag die 
dominee wil ontmoet, teenoor die $41 \%$ vroue. In die kategoriale gemeentes het $37 \%$ manlike respondente positief gereageer op dieselfde vraag teenoor $62 \%$ vroulike respondente. Die redes vir die verskille is nie duidelik nie. Wat die verskillende ouderdomskategorieë betref, kon daar geen tendens waargeneem word nie. Dit beteken dat daar nie noodwendig by 'n spesifieke ouderdomsgroep 'n groter behoefte bestaan om met die dominee kennis te maak, as by ander ouderdomsgroepe nie. Die belangrikste saak, soos hierbo vermeld word, is die oorweldigend (98\%) positiewe respons ten opsigte van die vraag oor die huisbesoek van die predikant aan nuwe intrekkers.

Hierdie besoeke aan nuwe intrekkers moet addisioneel tot en ter aanvulling van die gewone huisbesoek plaasvind. Die tyd wat daaraan afgestaan word, kan radikaal van gemeente tot gemeente verskil. Beplanning in dié verband is van die uiterste belang. Met dít in gedagte, kan die volgende voorlopige teorie oor besoeke aan nuwe intrekkers voorgestel word:

* Besoeke aan nuwe intrekkers deur die predikant behoort 'n pertinente plek in sy gemeentelike werksaamhede te hê. Dit moet nie as gewone huisbesoek gesien word nie, maar as ' $\mathrm{n}$ informatiewe besoek (vgl Berkelbach van der Sprenkel 1946: 32) wat addisioneel tot en ter aanvulling van die gewone huisbesoek plaasvind. Die doel daarvan is dat dit moet bydra in die vestiging van 'n pastorale relasie tussen predikant en lidmaat om sodoende die pastorale werksaamhede van die predikant te bevorder en die koinonia in die gemeente te versterk.

\section{DIE VOORLOPIGE TEORIE OOR BESOEKE AAN NUWE INTREKKERS GETOETS AAN PERSPEKTIEWE UIT DIE SKRIF}

Volgens die metodologiese model wat gebruik word, moet die voorlopige teorie aan die Skrif getoets word. Dit is egter baie moeilik om dit te doen omdat besoeke aan nuwe intrekkers glad nie in die Bybel voorkom nie. Om die teorie oor die belangrikheid van besoeke aan nuwe intrekkers aan die Skrif te toets, kan dus baie maklik daartoe lei dat dinge in die Bybel ingelees word, of dat die Bybel so gebruik word dat dit moet buikspreek om die teorie te kondoneer. So 'n werkwyse is nie alleen ontrou aan die Skrif nie, maar dit kan ook nie op wetenskaplikheid aanspraak maak nie. Dit is daarom onmoontlik om die voorlopige teorie, soos dit hierbo geformuleer is, aan die Skrif te toets.

In die lig hiervan word 'n werkwyse gekies waarin daar hoogstens gevra kan word of die geponeerde voorlopige teorie nie dalk in stryd met die Skriftuurlike perspektiewe is nie en of dit die breë doel van kerkwees en verkondiging dien. Daar sal dus gepoog word om sekere beginsels of begrippe uit die teorie af te lei en dit dan aan so 'n Skriftoets te onderwerp. Die volgende beginsels/begrippe kan uit die voorlopige teorie afgelei word: 
* Besoeke aan nuwe intrekkers moet bydra tot die vestiging van ' $n$ persoonlike/ pastorale relasie tussen die predikant en lidmaat.

* Besoeke aan nuwe intrekkers moet help om die gemeente nader aan mekaar bring (koinonia).

* Omdat lidmate te kenne gegee het dat hulle makliker na die predikant sal gaan met 'n persoonlike probleem as hulle hom tydens die huisbesoekgesprek persoonlik leer ken het, kan die besoeke aan nuwe intrekkers 'n belangrike rol speel in die predikant se pastorale werksaamhede en dus ook voorkomend funksioneer.

* Besoeke aan nuwe intrekkers beklemtoon die teologiese teorie (vgl Van Zyl 1995: $137,138)$ dat dit in die huisbesoek oor die indiwidu binne die verband van sy/haar gesin gaan.

* Luister is baie belangrik tydens besoeke aan nuwe intrekkers. Met so ' $n$ eerste besoek kan waardevolle inligting omtrent die nuwe lidmaat/gesin ingewin word.

* Die opsigtaak van die pastor kom ook duidelik na vore waar hy/sy uitgaan om nuwe lidmate op te soek.

Aangesien Louw (1993) wyd oor die pastorale gesprek in die algemeen gehandel het (besoeke aan nuwe intrekkers vorm sekerlik deel van pastorale gesprekke), en reeds verskeie van hierdie begrippe en beginsels na aanleiding van 'n pastorale gespreksituasie aan die Skrif getoets het, sal hier onder andere op sy bevindinge gesteun word.

Louw (1993:22-32) neem as vertrekpunt vir die pastorale gesprek die begrip sorg (vgl ook Pieterse 1991:4). Hy poog dan ook om die sorggedagte vanuit drie Bybelse metafore te belig. Dit wat hy oor elkeen van dié drie metafore stel, verifieer reeds verskeie van die beginsels of begrippe wat hierbo in die voorlopige teorie beklemtoon is, se Bybelse begronding.

Louw begin met die herdermetafoor. 'God versorg die hele skepping en pas in ' $n$ heel besondere sin die mens op soos 'n herder. Klassiek is Psalm 23: "Die Here is my herder ek kom niks kort nie”' (Louw 1993:23; vgl ook Westermann 1984:95-98, 2634; Odendaal 1988:56-60; De Klerk 1978:2-17; Rossouw 1988:304; Heyns 1986:4852; NAB 1983). Westermann (1984:96) wys daarop dat die herdermetafoor wat ook in Psalm 80 voorkom, die besondere verhouding wat tussen God en die gelowige bestaan, belig. 'Der Dichter des Psalms verweilt bei diesem Vergeleich und entfaltet ihn: was 
der Hirt für die Herde bedeutet, das bedeutet Gott für mich' (Westermann 1984:96). Odendaal (1988:57) sluit hierby aan en stel dat Psalm 23 'n pragtige uitdrukking van die gelowige se vertroue in God is. 'Die Psalm val ongetwyfeld op as ' $n$ uitdrukking van persoonlike geloofsvertroue' (Odendaal 1988:57; vgl ook Van Uchelen 1979:159).

Hierdie perspektief van die metafoor is tog belangrik vanweë die feit dat sommige skrywers (vgl Hendriks 1992:69) in hulle beskrywing van die opbou (oikodomeo) van die gemeente, die indiwiduele gelowige totaal buite rekening laat. Die herdermetafoor skep pertinent ruimte vir die indiwidu, al is dit binne die verband van die groep (trop) (vgl ook Anderson 1972:196; Van Uchelen 1979:158-161; Louw 1993:28).

Sonder om die herdermetafoor op die voorlopige teorie af te forseer, is dit duidelik dat die meeste van die begrippe/beginsels wat uit die voorlopige teorie afgelei is, binne die skopus van dié metafoor val.

Die vestiging van ' $n$ pastorale relasie tussen predikant en lidmaat (herder en skape), waarin luister ook 'n belangrike rol speel, word pragtig deur hierdie metafoor ondervang (vgl Martin 1992:257-261). Hierdie metafoor sluit ook in dat dit oor die indiwidu binne die verband van die gesin (sisteem-teorie) gaan. Die 'herder' (pastor) ken elke 'skaap' (indiwidu) op sy naam (Joh 10), maar lei tog ook die hele trop (gesin/gesinne) (vgl Rossouw 1988:302; Anderson 1972:196: Van Uchelen 1979:160; Morris 1971:509-512).

Die opsigtaak van die herder (om in liefde op te soek) kom ook in hierdie metafoor sterk na vore, soos veral gesien kan word in die gelykenis van die verlore skaap (Matt 18:10-14; Luk 15:1-7, NAB 1983; vgl ook Marshall 1978:600-602).

Die moontlikheid van 'n sinvolle gesprek tydens huisbesoek word bevorder deur die verhouding wat tussen die herder en lidmaat geskep word (wat met die besoek van 'n nuwe intrekker kan begin). 'n Besoek aan 'n nuwe intrekker kan ook daartoe bydra dat die lidmaat die vrymoedigheid verkry om sy/haar probleme tydens gewone huisbesoek te bespreek waardeur die pastorale werksaamhede van die predikant bevorder word (vgl die $86 \%$ lidmate wat gesê het dat hulle makliker na die predikant sal gaan met 'n persoonlike probleem as hulle hom reeds in die huisbesoekgesprek leer ken het). Dit dui ook daarop dat besoeke aan nuwe intrekkers 'n voorkomende uitwerking kan hê. Die verhouding wat tussen die herder en die lidmaat gevorm word (wat met kennismaking kan begin), kan by die lidmaat die vrymoedigheid skep om 'n latente probleem na die oppervlak te bring waardeur verdere gevolge moontlik voorkom kan word. Die openhartige gesprek wat uit 'n sinvolle relasie tussen predikant en lidmaat kan volg, kan dus ook daartoe bydra dat die huisbesoek as klankbord vir die prediking kan dien.

Die deernisvolle en ontfermende liefde van die pastor (herder) vorm die basis vir die besoeke aan nuwe intrekkers. Omdat die herder die heil van elke skaap op die hart dra, sal hy/sy poog om elke nuwe aankomeling so spoedig as moontlik beter te leer 
ken, te betrek en deel van die trop te maak. Dit is juis die liefde wat gelowiges dring om met mekaar te praat, om mekaar te bemoedig, by mekaar betrokke te wees en deel van 'n gemeente te wees (vgl Louw 1993:247-248, 395, 447-448; Louw 1980(b):60; Dreyer 1987:5; Faber \& Van der Schoot s a 91-92). Al hierdie sake word die beste beskryf met die woord koinonia (vgl Prins 1986:35). Dit is juis deur opregte liefde vir God en medegelowiges dat koinonia in 'n gemeente bevorder word (vgl, De Klerk 1986 :8,15). Panikulam (1979:1) verwys na drie tekste in die Nuwe Testament, naamlik 1 Korintiërs 1:9, Handelinge 2:42 en 1 Johannes 1:3 om, soos hy dit stel, 'the essence of Christianity in one word ... koinonia ...', te beskryf. Uit wat hierbo gesê is, is dit duidelik dat besoeke aan nuwe intrekkers 'n belangrike rol kan speel om koinonia in 'n gemeente te bevorder.

Die volgende metafoor waarmee Louw (1993:25) die sorggedagte van die pastoraat beskryf, is die dienskneg-metafoor (vgl ook Newman \& Nida 1972:107; Venter 1992: 11). Hy gebruik hierdie metafoor veral om God se identifikasie met die lyding van die mens te beskryf:

Die diensknegmetafoor lê 'n unieke verband tussen God se medelye en menslike lyding as gevolg van sonde, siekte, vervolging, ontwrigting en dood .... Die identifikasie van God met menslike lyding tree duidelik na vore in die werk van Jesus Christus. Hy is God se doulos by uitstek (Mat 12:18; Hand 4:27).

(Louw 1993:25)

Indien 'n mens hierdie metafoor, soos Louw dit beskryf, slegs in terme van die genesing en herstel van die mens sien, sou dit meer van toepassing gewees het op die besondere pastoraat waar dit oor mense met probleme gaan. Alhoewel die hantering van probleme nie die hoofskopus van huisbesoek is nie, lê dit ook nie heeltemal buite die fokus nie (vgl Van Zyl 1995:117-130). Soos reeds aangetoon is, skep besoeke aan nuwe intrekkers die vrymoedigheid by die lidmaat om sy/haar probleme met hulle predikant te bespreek.

Die derde metafoor waarmee Louw (1993:27-32) die pastoraat beskryf, is die paraklesemetafoor. Hy gebruik verskillende Bybelse begrippe om die sorgkarakter van die pastoraat te onderstreep. Van al hierdie begrippe beskou hy die begrip oikodomein as die mees sentrale. 'Pastorale sorg is ten diepste gemeente-opbou sodat elkeen opgebou kan word "as lewende stene tot ' $n$ geestelike huis om 'n heilige priesterdom te wees en geestelike offers te bring" (1 Pt 2:5)' (vgl ook Louw 1982:11; De Klerk 1978:16-17; Smit 1988: 201-204; Knepper 1991:28,29). Hendriks (1992:76) haal ook 1 Petrus 2:5 in dié verband aan: 'Laat julle as lewende stene opbou tot 'n geestelike huis ...', om 
die belangrikheid van die begrip oikodomein uit te lig. Wat egter belangrik is, is die subjek en objek van die oikodomein. Volgens Hendriks (1992:37-86) is die Drie-enige God die subjek van die oikodomein (vgl ook Martin (1992:69). Wat die objek aanbetref, loop hy (1992:69), soos vroeër vermeld, die gevaar om die indiwidu binne die gemeente te verloor. In sy stelling: 'Die objek van die bouwerk is uiteindelik altyd die ekklesia, nie die indiwiduele gelowige nie', laat hy nie ruimte dat die ekklesia uit indiwiduele stene (lidmate) bestaan wat elkeen alleen en saam opgebou moet word 'tot 'n geestelike huis ...' (vgl ook Louw 1993:28; Knepper 1991:29). Besoeke aan nuwe intrekkers kan 'n belangrike funksie vervul ten opsigte van die opbou van die gemeente. Dit kan daartoe bydra om lidmate spoedig te betrek en deel van die ekklesia te maak.

Vir Louw (1993:29) is die begrip parakalein waarmee hy die pastoraat binne die betekenisveld van die paraklesemetafoor beskryf, baie sentraal. Hy meen dat dié woord die beste uitdrukking gee aan die 'inhoud en styl van die pastorale troosfunksie en sorghandelinge ...' (vgl ook Louw 1982:8-15; De Klerk 1978:12-14). Hy sien die woord veral in terme van die Nuwe-Testamentiese betekenisnuanses daarvan, naamlik oproep, uitnodiging, teregwysing, vermaning, troos, bemoediging en bystand (vgl Thayer 1961; Arndt \& Gingrich 1974). Miskien wil hierdie begrip (parakalein), en dan veral in die betekenis van uitnodiging, die beste uitdrukking gee aan die besoeke aan nuwe intrekkers.

In hierdie ondersoek na die beginsels/begrippe wat ten opsigte van die voorlopige teorie uitgelig is, kon niks gevind word wat in die Bybel weerspreek word nie. Die voorlopige teorie oor besoeke aan nuwe intrekkers sal die toets van die Skrif deurstaan, en kan dus onverkort as nuwe teorie gekonstateer word.

\section{5. 'N NUWE PRAKTYKTEORIE TEN OPSIGTE VAN BESOEKE AAN NUWE INTREKKERS}

Die besoeke aan nuwe intrekkers is so belangrik dat dit kerkordelik gereël behoort te word. Hier sal kortliks 'n voorstel gedoen word oor die wyse waarop dit in die praktyk van kerk-wees geïmplementeer behoort te word.

'n Artikel, genaamd Pastoraat, behoort in die Kerkorde of Kerkwet opgeneem te word. Hierdie artikel kan verskillende bepalings/ordinansies insluit waarvan huisbesoek ' $n$ pertinente onderdeel behoort te wees. Bo en behalwe die bepalings/ ordinansies wat onder andere oor die doel, vorm, inhoud en frekwensie van huisbesoek behoort te handel, moet daar ook ' $n$ bepaling/ordinansie wees wat die besoeke aan nuwe intrekkers kerkordelik reël (vgl Van Zyl 1995:292, 293). So 'n bepaling/ordinansie kan die volgende insluit: 
* Die predikant moet poog om nuwe intrekkers waarvan hy bewus is, binne drie maande nadat hulle ingetrek het, te besoek om kennis te maak. Dit moet nie as 'n gewone huisbesoek gesien word nie, maar as 'n informatiewe besoek wat addisioneel tot die gewone huisbesoek plaasvind. Die doel daarvan is om mee te help in die vestiging van 'n pastorale relasie tussen predikant en lidmaat om sodoende die pastorale werksaamhede van die predikant te bevorder en die bou van koinonia in die gemeente te bevorder.

'n Praktykmodel sou verder kon bepaal dat daar 'n spesifieke ouderling gekies word in die gemeente met die opdrag om nuwe intrekkers in die gemeente in te skakel. 'n Werkgroep sou ook oorweeg kon word waarby lidmate betrek word wat bereid is om te help om nuwe lidmate in te skakel en deel van die gemeente te maak.

\section{SLOT}

Die hipotese oor besoeke aan nuwe intrekkers wat aan die begin gestel is, kan onverkort gehandhaaf word. Die Kerk behoort dus hierdie belangrike saak op die agendas van al die kerklike vergaderings te plaas, om dit sodoende so spoedig as moontlik te implementeer as deel van die werksaamhede van die gemeentepredikant.

\section{Literatuurverwysings}

Adams, J E 1981. Shepherding God's flock. 3rd ed, New Jersey: Presbyterian and Reformed Publishing Company.

Anderson, A A 1972. Psalms, vol 1, in Clements, R E \& Black, M (ed), New century Bible. Great Britain: Purnell \& Sons.

Arndt, W F \& Ginrich, F W 1957. A Greek-English lexicon of the New Testament and other early Christian literature. Chicago: University of Chicago press.

Berkelbach van der Sprenkel, S F H J 1946. Huisbezoek. Amsterdam: Ploegsma.

Booysen, D J 1990. Huisbesoek. HTS 46/4, 567-581.

Bouwman, H 1928. Gereformeerd Kerkrecht, Vol 1. Kampen: Kok.

De Klerk, J J 1978. Herderkunde. Pretoria: N G Kerkboekhandel.

1986. Die koinoniale aard van die gemeente, in Diakonia en koinonia. Pretoria: N G Kerkboekhandel.

Deddens, K 1988. Dient Hem met vreugde: Opstellen over de dienst van de ambtsdragers, 1. Den Haag: Oosterbaan \& Le Cointre B.V. Goes.

Die Bybel, 1983. 9e druk. Kaapstad: Die Bybelgenootskap van Suid-Afrika.

Die Hervormer 1 September 1990. Waarom word huisbesoek afgeskeep?, bl 3.

— 1 Desember 1990. Huisbesoek nie so belangrik, bl 4.

— 1 Februarie 1991. Huisbesoek is evanglieverkondiging, bl 4. 
Die Hervormer 1 Februarie 1991. Huisbesoek: 'n hulpmiddel, bl 6.

Die Kerkbode Maart 1991, deel 147. Huisbesoek is uitgedien sê die professor toe, bl 5.

Julie 1991, deel 148 no 3. Huisbesoek speel onvervangbare rol in gemeentebouprogram, bl 4.

_- Oktober 1991, deel 148 no 14(bylae). Huisbesoek is 'n moet, hoor N-Tvl, bl 1.

Dixon, I 1976. A Theology of pastoral visiting. ET 87, 264-267.

1987. A Practical Theology af pastoral visiting. The Christian Ministry 18, 18-19.

Dreyer, T F J 1987. Pastorale gesprekvoering. Ongepubliseerde Kernaantekeninge Poimeniek 1. Universiteit van Pretoria.

- 1991. Eerste treë in die praktiese teologie - waarheen? HTS 47/3, 597-608.

Faber, H \& Van der Schoot, E s a. Het pastorale gesprek. Utrecht: Erven J Bijleveld. Heitink, G 1982. Het protestantse huisbezoek vroeger en nu. PrakTH 9, 303-312.

Hendriks, J 1992. Strategiese beplanning in die gemeente: Die beginsels en praktyk van gemeentevernuwing. Wellington: Hugenote-uitgewers.

Heyns, L M 1986. 'n Prakties-teologiese ondersoek na die kerklike strukture van die Nederduitse Gereformeerde Kerk. DTh-proefskrif, Universiteit van Suid-Afrika.

Heyns, L M \& Pieterse, H J C 1990. Eerste treë in die praktiese teologie. Pretoria: Gnosis.

Hocking, M 1985. The Smiths and the Jones: A handbook of pastoral work. 2nd ed. Mowbray London: Oxford.

Horton, W D 1981. The pastor's problems. ET 92, 100-103.

Kaptein, R 1975. Het huisbezoek: Problematiek en metode in een veranderde gemeente. Baarn: Ten Have.

Knepper, J A 1991. Een geestelijk huis van levende stenen: Gemeente-opbouw in de praktijk rond het jaar 2000. Den Haag: Oosterbaan \& Le Cointre B V.

Kuyper, N A 1980. Are pastors 'called' to home visitation? ChrTo 24, 38.

Lemmer, J C 1991. Hipotese-generende ondersoeke in prakties-teologiese navorsing.

Praktiese Teologie in Suid-Afrika 6/1, 10-19. Pretoria: N G Kerkboekhandel.

Louw, D J 1980a. Die stad in die mens: Oor kerk-wees vandag. Pretoria: N G Kerkboekhandel.

1980b. Op soek na die huisgenote van die geloof: Riglyne vir huisbesoek. Pretoria: N G Kerkboekhandel.

1982. Pastoraat en lyding. Kaapstad: N G Kerkuitgewers. (Teologie aktueel 1.) 
Louw, D J 1993. Pastoraat as ontmoeting: Ontwerp vir 'n basis-teorie, antropologie, metode en terapie. Pretoria: RGN.

Marshall, I H 1978. Commentary on Luke. Michigan: Eerdmans. (New international Greek Testament Commentary.)

Martin, T W 1992. Metaphor and composition in 1 Peter. Atlanta, Georgia: Scholars Press.

Morris, L 1971. The gospel according to John. Michigan: Eerdmans.

Muller, J C 1985. Huisbesoek te midde van veranderde omständighede. NGTT 26/3, 311-318.

Nel, M 1991. Die wisselwerking tussen teorie/praxis in die Praktiese Teologie. Praktiese Teologie in Suid-Afrika 6/1, 22-37.

Newman, B M \& Nida, E A 1972. A translator's handbook on the Acts of the apostles. London: United Bible Societies.

Odendaal, D H 1988. Psalm 23, in Burger, C W, Müller, B A \& Smit, D J (red), Riglyne vir die prediking oor die Psalms, 56-60. Kaapstad: N G Kerkuitgewers.

Panikulam, G 1979. Koinonia in the New Testament: A dynamic expression of Christian life. Rome: Biblical institute press.

Pieterse, H J C 1986. Praktiese Teologie mondig? Skrif en Kerk 7/1, 63-73. 1991. Gemeente en prediking. Pretoria: N G Kerkboekhandel.

Piper, H C 1985. Der Hausbesuch des Pfarrers: Hilfen für die Praxis. Göttingen: Vandenhoeck \& Ruprecht.

Prins, J M G 1986. Die koinoniale nood van die mens van vandag, in Diakonia en koinonia. Pretoria: N G Kerkboekhandel.

Rossouw, P J 1988. Gereformeerde ampsbediening. Pretoria: N G Kerkboekhandel.

Smit, J H 1988. Kerk, sending en amp - 'n organiese eenheid, in Rossouw, P J (red), Gereformeerde ampsbediening, 196-216. Pretoria: N G Kerkboekhandel.

Stoker, D J 1981. Steekproefneming in die praktyk. Universiteit van Pretoria.

Thayer, J H 1961. Greek-English lexicon of the New Testament, 4th ed. Edinburgh: T \& T Clark.

Van der Geest, H 1981. Unter vier Augen: Beispiele gelungener Seelsorge. Zürich: Theologischer Verlag.

Van Uchelen, N A 1979. Psalmen, deel 1. 2de druk. Nijkerk: Callenbach. (De Prediking van het Oude Testament.)

Van Zyl, P J 1995. 'n Prakties-Teologiese ondersoek na die invloed van huisbesoek op erediensbywoning binne die Nederduitsch Hervormde Kerk van Afrika. DD-proefskrif, Universiteit van Pretoria. 
Venter, C J H 1992. Prakties-Teologiese grondslae van die prediking. Praktiese Teologie in Suid-Afrika 7/1, 1-16.

Vos, C J A \& Müller, J C 1991. Die sing van Psalms in die erediens: 'n Kommunikatiewe handelingsteoretiese perspektief. Praktiese Teologie in Suid-Afrika 6/1, 86-98.

Wagenaar, J P J [1984]. Die kerk se pastorale taak ten opsigte van die moderne stadsmens. HTS 39, 84-91.

Westermann, W 1984. Ausgewählte Psalmen. Göttingen: Vandenhoeck \& Ruprecht.

Zerfass, R 1974. Praktische Theologie als Handlungs-wissenschaft, in Klostermann, F \& Zerfass, R (Hrsg), Praktische Theologie heute. München: Kaiser/Grünewald. 